UDC 81'23:[316.775.2:141.22

DOI https://doi.org/10.24919/2308-4863/39-1-23

\author{
Valentina BOICHUK, \\ orcid.org/0000-0002-9870-2195 \\ Candidate of Philological Sciences, \\ Senior Lecturer at the Department of Philology \\ Municipal Higher Educational Institution "Lutsk Pedagogical College" \\ of the Volyn Regional Council \\ (Lutsk, Ukraine)boichukvalia@gmail.com
}

Nataliia YEFREMOVA, orcid.org/0000-0003-1476-1831

Candidate of Philological Sciences, Associate Professor, Associate Professor at the Conversational English Department

Lesya Ukrainka Volyn National University (Lutsk,Ukraine) yefremova05@gmail.com

Yulia SKROBAKA, orcid.org/0000-0001-5942-2783

Candidate of Pedagogical Sciences, Lecturer at the Department of Philology Municipal Higher Educational Institution "Lutsk Pedagogical College" of the Volyn Regional Council

(Lutsk,Ukraine) chapiuk@ukr.net

\title{
NON-COOPERATIVE STRATEGY FOR NEGATIVE SELF-EXPRESSION OF A PESSIMISTIC COMMUNICANT
}

The article highlights the non-cooperative strategy for negative self-expression of a pessimistic communicant. It is revealed that communicative strategy, as one of the most important discourse-forming factors, is a characteristic feature of pessimistic discourse, which presupposes a communicative situation of pessimistic behaviour, is represented by a complex system of lexical, syntactic, stylistic, pragmatic and non-verbal means of expressing the communicant's pessimistic outlook and is characterized by certain goals, style, tonality and mode of communication.

Strategies for the expression of pessimism harmonize or disharmonize relationships between the interlocutors. The strategy for negative self-expression as a rigid non-cooperative communicative strategy is realized by the tactics of affectation, demonstration of negative expectations, demonstrative self-criticism, self-accusation, self-humiliation, complaints and sarcasm. As the purpose of a pessimist is to find himself/herself in the centre of attention and to get psychological support from an interlocutor, the main motivating factor for the use of a negative self-expression strategy in pessimistic discourse is his/her egocentrism.

The verbal markers of non-cooperative strategy for negative self-expression of a pessimistic communicant are lexico-semantic, syntactic, stylistic and pragmatic means. The verbalization of the tactics realising the strategy for negative self-expression of a pessimistic communicant is determined by the structure of a communicative situation and by the peculiarities of the personal behavioural responses of a pessimistic communicant. It is proved that the choice of the strategy for negative self-expression of a pessimistic communicant and its tactics is determined by typological peculiarities of pessimism as a dispositional and attributional phenomenon.

Key words: communicative strategy, non-cooperative strategy, communicative strategy for negative self-expression, pessimistic discourse, communicative tactics, pessimistic communicant. 


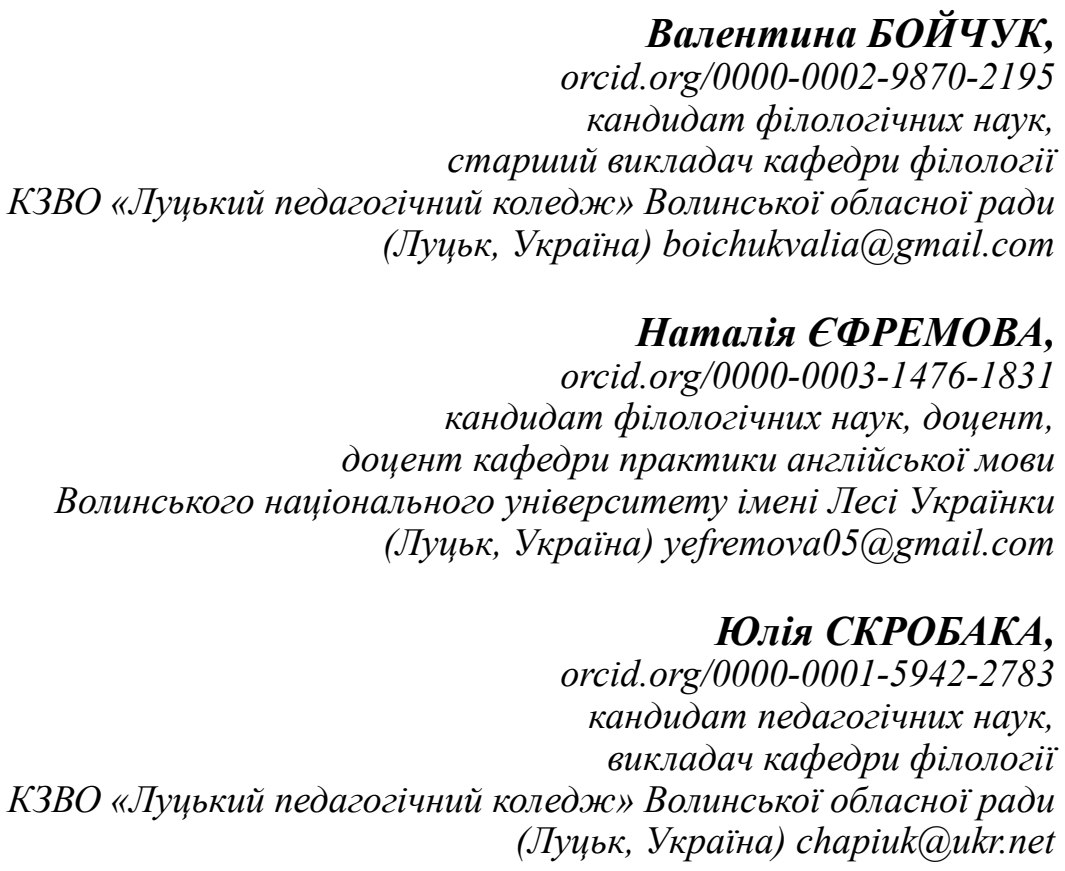

\section{НЕКООПЕРАТИВНА СТРАТЕГІЯ НЕГАТИВНОГО САМОВИРАЖЕННЯ КОМУНІКАНТА-ПЕСИМІСТА}

У статті виявлено особливості реалізаџії некооперативної стратегії негативного самовираження комуніканта-песиміста. Комунікативна стратегія, дворівневий характер якої визначається нормами соиіуму $і$ диспозиціями психологічної структури особистості, є основою песимістичного дискурсу. Песимістичний дискурс розглядаємо як особистісно орієнтований тип дискурсу, який передбачає наявність комунікативної ситуаціі реалізаиії песимізму мовия. Він представлений комплексною системою лексичних, фразеологічних, синтаксичних, стилістичних і прагматичних засобів репрезентації песимістичного світобачення мовця й характеризується власними цілями, стилем, тональністю та комунікативними стратегіями.

Серед низки жорстких некооперативних стратегій виокремлено стратегію негативного самовираження, яка реалізується тактиками афектації, демонстрачії негативних очікувань, демонстративної самокритики, самозвинувачення, самоприниження, нарікання, сарказму.

Когнітивним підгрунтям негативного самовираження особистості, як окремого типу деструктивної комунікативної поведінки, є низка особистісних психологічних комплексів - комплексу неповноцінності, комплексу меншовартості та комплексу провини. Основним мотивуючим чинником застосування стратегії негативного самовираження у песимістичному дискурсі є егоиентризм песиміста, мета якого - опинитися в иеетрі уваги й отримати від співрозмовника психологічну підтримку.

Вербальними маркерами стратегій та тактик, що ними послуговується комунікант-песиміст, є лексикосемантичні, синтаксичні, стилістичні та прагматичні засоби. Доведено, щяо вибір комунікантом-песимістом некооперативної стратегї негативного самовираження та ї̈ тактик визначається типологічними особливостями песимізму як диспозиційного та атрибутивного феномена.

Ключові слова: комунікативна стратегія, некооперативна стратегія, комунікативна стратегія негативного самовираження, песимістичний дискурс, комунікативна тактика, комунікант-песиміст.

Formulation of the problem. The study of communicative behaviour of the participants of communication will inevitably address the problem of communicative strategy, the two-level character of which is determined by the rules of society and dispositions of the individual psychological structure. Being the optimal implementation of the speaker's intentions to achieve a specific goal of communication, the communicative strategy determines the control and selection of certain ways of behaviour at a certain stage of communicative interaction, aimed at obtaining the desirable or preventing undesirable effect (com- municative tactics) and their flexible modifications in a particular communicative situation (Бацевич, 2004: 118-120).

Communicative strategy as one of the most important discourse-forming factors is a basic feature of pessimistic discourse, which presupposes a communicative situation of realization of the speaker's pessimism. It is represented by a complex system of lexical, syntactic, stylistic and pragmatic means of representation of a speaker's pessimistic world view, and is characterized by its own goals, style, tenor and communicative strategies. 
Since the notion of communicative strategy is one of the central notions in the analysis of any type of discourse, the interest of researchers to various aspects of its study remains consistently high. Currently, the main features of communicative strategies have been defined, the existing classifications of communicative and discursive strategies have been reviewed (Исcеpc, 2008; Максимова, 2005; Christensen, Svensson, 2017; Plowman, Wilson, 2018), the peculiarities of strategies and tactics of communicants in different types of discourse are revealed (Brown, White, 2010; Anesa, 2020), etc. Pessimism as a worldview heterogeneous construct, which determines the choice of verbal and non-verbal means of communication, underlies a certain type of communicative behaviour. The discourse analysis of a pessimistic communicant's strategies and tactics is one of the stages in the research of their communicative behaviour.

The aim of this research is to identify the characteristic features of non-cooperative strategy for negative self-expression of a pessimistic communicant. The specific research objectives are as follows: 1) to reveal the tactics realising the non-cooperative strategy for negative self-expression of a pessimistic communicant; 2) to identify the verbal markers of non-cooperative strategy for negative self-expression of a pessimistic communicant and its tactics; 3 ) to establish the connection between the typological features of pessimism as a psychological phenomenon and non-cooperative strategy for negative self-expression of a pessimistic communicant and its tactics.

Presentation of the main research material. The rules for the language use and norms of social interactions, which make up a conceptual scheme of discourse construction, are grounds for providing communicative and social needs of the participants of communication. These are the principle of cooperation and the principle of politeness that regulate and optimize informative (rational) and non-informative (sociative) facets of pessimistic discourse (Одарчук, 2009: 148). According to the degree of maintenance and violation of communication principles, pessimistic discourses are divided into those harmonizing and disharmonizing the relationships between communicants.

Taking into account the criterion of rigidity/softness of communicative strategies, which is based on the factor of communicative aggression/tolerance, non-cooperative communicative strategies for the expression of pessimism are defined as rigid, since their use leads to neglection of the cooperation and politeness principles. Cooperative communicative strategies for the expression of pessimism are soft, as they presuppose speaker's inclination to avoid conflicts, their ability to compromise, support of the interlocutor.
The realization of non-cooperative or cooperative communicative strategies for the expression of pessimism is determined by the conditions of each separate communicative situation and communicative needs of a pessimist in self-expression, confrontation, achieving communicative influence on the interlocutor, demonstration of tolerance and self-defence.

While analyzing the data, we have singled out a number of initial and responding communicative strategies that are characterized by these features and are realized by a relevant set of tactics. Rigid non-cooperative communicative strategies are: for negative self-expression, manipulation and confrontation. The use of these communicative strategies is determined by the fact that a pessimist as a person with clearly pronounced worldview principles demonstrates a number of personal characteristics that correlate with the basic features of pessimism and hinder communication in a number of communicative situations.

Self-expression of a personality, as an external actualization of his/her own beliefs and feelings, is an act of will, which is based not on their rational awareness, but on the spontaneity of expression. The cognitive basis of negative self-expression, as a separate type of destructive communicative behaviour, is a number of personal psychological complexes inferiority complex, minority complex and guilt complex. The main motivating factor for the use of a negative self-expression strategy in pessimistic discourse is the egocentrism of a pessimist, whose purpose is to find themselves in the centre of attention and to get psychological support from an interlocutor. This strategy is realized by the tactics of affectation, demonstration of negative expectations, demonstrative self-criticism, self-accusation, self-humiliation, complaints and sarcasm.

The communicative tactic of affectation is realized through the spontaneous expression of speaker's negative emotions. In the communicative situation of a spontaneous manifestation of negative emotions, a pessimist is experiencing an increase or weakening of emotional tension. The analyzed tactic is a spectacular example of violation of cooperation and politeness principles by G. Grais, which leads to the discord in communicative interaction. The verbal realization of this tactic is represented by the use of affectives, which indicate the pessimistic communicative behaviour of the speaker, and a number of syntactic stylistics devices. For example:

But still she clung to him, wailing aloud in her despair: "Oh, Jurgis, think what you are doing! It will ruin us - it will ruin us! Oh, no, you must not do it! No, don't, don't do it. You must not do it! It will drive me mad - it will kill me - no, no, Jurgis, I am 
crazy - it is nothing. You do not really need to know. We can be happy - we can love each other just the same. Oh, please, please, believe me!" (Sinclair).

The fictional heroine uses a tactic of affectation, the basis of which is guilt complex, and tries to obtain psychological support from her interlocutor. "Hopelessness", "disbelief", "negative expectations", "despair", "suffering", "fear", "nervousness" as qualitative features of pessimism are represented in the speech: 1) by a one-word exclamation $\mathrm{Oh}$, the pessimistic potential of which is determined by the context; 2) by an exclamatory sentence (Oh, Jurgis, think what you are doing! It will ruin us - it will ruin us! Oh, no, you must not do it! Oh, please, please, believe me!); 3) by lexical and syntactic repetitions helping the speaker to draw attention and cause interest in interlocutors (It will ruin us - it will ruin us! Oh, no, you must not do it! No, don't, don't do it. You must not do it! no, no; please, please), enhance pessimistic tonality of the utterance; 4) by parallel constructions (It will drive me mad - it will kill me; We can be happy - we can love each other just the same.). Simultaneous use of the kinesic pantomime (she clung to him) and phonatory (wailing aloud in her despair) non-verbal means of communication enhance the effect of affectation. The use of affectation tactic allows a pessimist to express negative emotions and achieve psychological safety valve.

The communicative tactic of demonstration of negative expectations is determined by a pessimist's crave for excessive self-expression, which is manifested in a constant attraction of attention to himself/ herself and a constant accentuation of negative expectations as a basic qualitative feature of pessimism. The violation of maxim of quantity (utterance falsifies on excessive information) and method (utterance is ambiguous and wordy) of the principle of cooperation by G. Grais leads to the disharmony in pessimistic discourse. The realization of this tactic takes place with the help of certain syntactic structures and stylistic means. For example:

"You're thinking too much, Bradley, I can see you are. We'll solve all these problems. We'll have Priscilla to live with us".

"We won't be living anywhere".

"What do you mean?"

"We just won't. There isn't any future. We shall go on and on driving in this car forever. That's all there is".

"You mustn't speak like that, it's false. Look, I've bought brown bread and toothpaste and a dustpan".

"Yes. That's a miracle. But it's like the fossils which religious men used to think God put there when He created the world in 4000 b.c. so that we could develop an illusion of the past".
"I don 't understand".

"We have an illusion of the future".

"That's wicked talk and a betrayal of love".

"Our love is in the nature of a closed system. It is complete within itself. It has no accidents and no extension".

"Please don't talk that abstract sort of language, it's a way of lying".

"Maybe. But we have no language in which to tell the truth about ourselves, Julian" (Murdoch).

In this example, the excessive demonstration of negative expectations is achieved by; 1) the repeated use of negative sentences: We won't be living anywhere. We just won't. There isn't any future. But we have no language in which to tell the truth about ourselves, Julian. It has no accidents and no extension; 2) irony as the speech means of excessive self-expression: That's a miracle. He created the world in 4000 b.c. so that we could develop an illusion of the past; 3) comparison: But it's like the fossils which religious men used to think God put there when He created the world in 4000 b.c. so that we could develop an illusion of the past. Our love is in the nature of a closed system; 4) metaphor: It (love) has no accidents and no extension.

Communicative tactics of demonstrative self-criticism, self-accusation and self-humiliation emphasize the negative personal features of a pessimist. The cognitive-psychological basis for these communicative tactics is low self-esteem, which is the ground for the formation of pessimism as an attributive style. Demonstrative self-criticism, self-accusation and self-humiliation differ in intensity and level of self-esteem: from demonstrative statement of the critical self-perception to exaggerated understatement of personal features and characteristics.

Pessimistic speech acts (constantives, assertives and expressives) which realize these tactics, express negative subjective-assertive attitude of a pessimist to his/her own actions and feelings.

The analyzed tactics are used by the speaker to demonstrate compliance with the principle of politeness, namely, the maxim of modesty (drive to maximum self-accusations and self-criticism). However, the violation of the maxims of number, mode (excessive information and wordiness) and relevance (deviation from the theme) of the principle of cooperation is the factor that contributes to the discord of interaction between communicants. The main means of realization of these tactics are lexical units with negative semantics and affectives which indicate pessimistic communicative behaviour of a speaker. Criticizing, accusing, humiliating himself/herself, a pessimist constructs pessimistic utterance around the egocen- 
tric lexeme - the pronoun $I$, which is the centre of pessimistic self-characterization. For example:

"I'm a failure," he murmured, "I'm unfit for the brutality of the struggle of life. All I can do is to stand aside and let the vulgar throng hustle by in their pursuit of the good things" (Maugham).

The communicative tactic of demonstrative self-criticism shows the speaker's intention to attract excessive attention, accentuating a number of qualitative features of pessimism, such as "failure" (I'm a failure), "uncertainty", "dissatisfaction" (I'm unfit for the brutality of the struggle of life), "passivity", "lack of interest", "lack of motivation", "apathy" (All I can do is to stand aside and let the vulgar throng hustle by in their pursuit of the good things), which indicate the inability of a pessimist to resist adverse external circumstances. The use of the phonatory non-verbal component of communication represented by the lexeme murmur, enhances the overall pessimistic tonality of the utterance.

The following example of the communicative tactic of self-accusation shows that the negative experience of the heroine contributes to the formation of a pessimistic attributive style.

She paused, hesitating, then with a shy half-laugh:

"I really believed I was selling myself, Mr Marlow. And I was proud of it. What I suffered afterwards I couldn't tell you; because I only discovered my love for my poor Roderick through agonies of rage and humiliation. I came to suspect him of despising me; but I could not put it to the test because of my father. Oh! I would not have been too proud. But I had to spare poor papa's feelings. Roderick was perfect, but I felt as though I were on the rack and not allowed even to cry out. Papa's prejudice against Roderick was my greatest grief. It was distracting. It frightened me. Oh! I have been miserable! That night when my poor father died suddenly I am certain they had some sort of discussion, about me. But I did not want to hold out any longer against my own heart! I could not" (Conrad, 2008: 197).

Sentiment-analysis proves that lexical units with negative semantics suffer (-1), agony (0), rage $(-1,5)$, humiliation $(-1,5)$, grief $(-1,5)$, distract $(-0,5)$, frighten $(-1,5)$, miserable $(0)$ and emotional exclamation $O h$ ! form a general pessimistic tonality of the utterance. Within the syntactic context the self-accusation tactic is realized through sentences that actualize the category of modality (I would not have been too proud. But I had to spare poor papa's feelings. Roderick was perfect, but I felt as though I were on the rack and not allowed even to cry out). Metaphor I was selling myself and metonymy against my own heart are stylistic means of realization of the analyzed tactic.
Self-humiliation as a typical mode of hypertrophied negative self-expression is characterized by the lowest level of self-esteem. For example:

I have rarely seen a man crying and the sight inspires disgust and fear. Francis was whimpering loudly, producing suddenly a great many tears. I could see his fat reddened hands wet with them in the light of the gas fire.

"Oh, cut it out!"

"All right, all right. Sorry, Brad. Forgive me. Please forgive me. I expect I just want to suffer. I'm a masochist. I must like pain or I wouldn't go on living, I'd have taken my bottle of sleeping pills years ago, I've thought of it often enough. Oh Christ, now you'll think I'm bad for Priscilla and boot me out" (Murdoch).

Humiliating himself/herself a pessimist tries not only to attract attention but also to get psychological support from the interlocutor. He does not realize that such communicative behaviour produces a reverse effect and increases the intensity of self-humiliation from excessive expression of consent with the interlocutor to intentions to commit suicide. Verbal markers of this tactic within the analyzed excerpt are: 1) lexical units with negative semantics suffer (-1), masochist $(-1)$, pain $(-1,5) ; 2)$ lexical and syntactic repetitions (All right, all right; Forgive me. Please forgive me); 3) the use of syntactic structures with modal words, modal verbs and conditional mood (I expect I just want to suffer. I must like pain or I wouldn't go on living, I'd have taken my bottle of sleeping pills years ago). Non-verbal components of communication (paralingual respiratory - whimpering loudly, producing suddenly a great many tear; somatic changes - fat reddened hands wet with them) complement and enhance verbalized information about the emotional state of the pessimistic communicant.

The communicative tactic of complaints as a means of negative self-expression is determined by the desire of a pessimist to attract the attention of the interlocutor to external factors that contribute to the formation of pessimistic dispositions. This goal presupposes the use of verbal and non-verbal means of communication that actualize relevant qualitative features of pessimism. By violating all the maxims of the principle of politeness and the maxim of mode of the principle of cooperation, this tactic contributes to the discord of pessimistic discourse. For example:

... Gabriel continued, "Have you ever really been happy?"

"Look!" snapped Sunday and his head whipped in the boy's direction to meet his cheery demeanor, "Not that it's any of your concern, but I don't have time for happiness because I'm too busy getting crapped 
on by a wicked Head Physician, nurses and kids like you!" (Hedges, 2009: 23).

The example shows the polychrosis of verbal and non-verbal actions, aimed at realization of the analyzed tactic, which allows to reveal such qualitative features of pessimism as "hopelessness", "irritation", "bad mood", "dissatisfaction", "nervousness". The phonatory (snapped) and kinesic (his head whipped) non-verbal components of communication accompany a number of multi-level linguistic means of implementing the analyzed tactic, such as: 1) an invective unit getting crapped on, 2) the adjective with negative semantics wicked, 3) distancing from the interlocutor Not that it's any of your concern, 4) the exclamatory sentence that reflects the hyperbolized sensibility of a pessimist.

The communicative tactic of sarcasm focuses the attention of the interlocutor on the negative attitude of a pessimist to a certain phenomenon. A pessimist as an egocentric but cautious personality, seeks self-expression by contrasting the literal and contextual meanings of pessimistic utterances. One of the factors that disharmonize interaction by the use of this tactic is the desire of a pessimist to achieve self-centred communicative purposes; the interests of the interlocutor are not taken into account. As an evaluative judgement, a pessimistic utterance with sarcastic semantics presupposes the speaker's rejection of certain phenomena of reality and the need to demonstrate their position. For example:

"I don't blame the girl", he was saying. "He is infatuated with her. /.../ He will be surprised", commented Fyne suddenly in a strangely malignant tone. "He shall be met at the jail door by a Mrs. Anthony, a Mrs. Captain Anthony. Very pleasant for Zoe. And for all I know, my brother-in-law means to turn up dutifully too. A little family event. It's extremely pleasant to think of. Delightful. A charming family party. We three against the world - and all that sort of thing. And what for. For a girl that doesn't care twopence for him". The demon of bitterness had entered into little Fyne. He amazed me as though he had changed his skin from white to black. It was quite as wonderful. And he kept it up, too (Conrad, 2008: 111).

The pessimist's negative attitude to the marriage of people with disproportion in age and different social status (And what for. For a girl that doesn't care twopence for him) is the reason for sarcasm. Verbalization of this tactic, which actualizes such qualitative features of pessimism as "negative expectations", "hopelessness", "despair", "dissatisfaction", "frustration", takes place due to: 1) the use of the indefinite article before proper nouns (a Mrs. Anthony), the repetition of which (a Mrs. Captain Anthony) enhances negative assessment and indicates the desire of the speaker to discredit the object of his utterance; 2) the use of lexical units with positive semantics (very pleasant, extremely pleasant, delightful, charming); 3) the repetition of the lexeme family and the use of synonyms event i party; 4) nominative sentences (A little family event. Delightful. A charming family party); 5) the use of hyperbole (We three against the world).

Conclusions. The choice of the non-cooperative strategy for negative self-expression of a pessimistic communicant and its tactics is determined by typological peculiarities of pessimism as a dispositional and attributional phenomenon. With all the findings, the current study needs to be further developed. The prospects touch upon the investigation of the phenomenon of pessimism in linguocultural aspect.

\section{BIBLIOGRAPHY}

1. Бацевич Ф. С. Основи комунікативної лінгвістики : підручник. Київ : Вид. центр «Академія», 2004.344 с.

2. Иссерс О. С. Коммуникативные стратегии и тактики русской речи. Москва : Издательство ЛКИ, 2008. 288 с.

3. Максимова Н. В. К основаниям типологии коммуникативных стратегий чужой речи. Исследования по семантике и прагматике языковых единиц. Уфа : Вагант, 2005. С. 109-114.

4. Одарчук Н. А. Відмова: семантичний та прагматичний аспекти : монографія. Луцьк : РРВ «Вежа» Волин. нац. ун-ту ім. Лесі Українки, 2009. 206 с.

5. Anesa P. Lovextortion: Persuasion strategies in romance cybercrime. Discourse, Context \& Media. 2020. Vol. 35. DOI: $10.1016 /$ j.dem.2020.100398.

6. Brown K. A., White C. L. Organization-public relationships and crisis response strategies: Impact on attribution of responsibility. Journal of Public Relations Research. 2010. Vol. 23: Iss. 1. P. 75-92. DOI: 10.1080/1062726X.2010.504792.

7. Christensen L. T., Svensson E. The nature of strategic communication: A rejoinder to Nothhaft. International Journal of Strategic Communication. 2017. Vol. 11. Iss. 3. P. 1-4. DOI: 10.1080/1553118X.2017.1318883.

8. Conrad J. Chance. Ed. by Martin Ray. 2008. 384 p.

9. Hedges R. Sweet Serene. Lulu. com, 2009. 324 p.

10. Maugham W. S. Of Human Bondage. URL: https://www.e-reading.club/bookreader.php/80509/Maugham_Of Human Bondage.htm

11. 'Murdoch I. The Black Prince. URL: https://www.e-reading.club/ bookresder.php/104708/blackprince.pdf.

12. Plowman K. D., Wilson Ch. Strategy and Tactics in Strategic Communication: Examining their Intersection with Social Media Use. International Journal of Strategic Communication, 2018. Vol. 12. Iss. 2, P. 125-144. DOI: 10.1080/1553118X.2018.1428979.

13. Sinclair U. The Jungle. URL: https://etc.usf.edu/lit2go/77/the-jungle/1261/chapter-1. 


\section{REFERENCES}

1. Batsevych F. S. Osnovy komunikatyvnoi linhvistyky [Fundamentals of communicative linguistics]. Kyiv: Vyd. tsentr "Akademiia", 2004. 344 p. [in Ukrainian].

2. Issers O. S. Kommunikativnye strategii i taktiki russkoy rechi [Communicative strategies and tactics of Russian speech]. Moskva: Izdatelstvo LKI, 2008. 288 p. [in Russian].

3. Maksimova N. V. K osnovaniyam tipologii kommunikativnykh strategiy chuzhoy rechi [To the fundamentals of the typology of another person's speech]. Studies on Semantics and Pragmatics of Language Units. Ufa: Vagant. P. 109-114 [in Russian].

4. Odarchuk N. A. Vidmova: semantychnyi ta prahmatychnyi aspekty [Refusal: semantic and pragmatic aspects]. Lutsk: RRV "Vezha” Volyn. nats. un-tu im. Lesi Ukrainky, 2009. 206 p. [in Ukrainian].

5. Anesa P. Lovextortion: Persuasion strategies in romance cybercrime. Discourse, Context \& Media. 2020. Vol. 35. DOI: 10.1016/j.dcm.2020.100398.

6. Brown K. A., White C. L. Organization-public relationships and crisis response strategies: Impact on attribution of responsibility. Journal of Public Relations Research. 2010. Vol. 23: Iss. 1. P. 75-92. DOI: 10.1080/1062726X.2010.504792.

7. Christensen L. T., Svensson E. The nature of strategic communication: A rejoinder to Nothhaft. International Journal of Strategic Communication. 2017. Vol. 11: Iss. 3. P. 1-4. DOI: 10.1080/1553118X.2017.1318883.

8. Conrad J. Chance. Ed. by Martin Ray. 2008. 384 p.

9. Hedges R. Sweet Serene. Lulu. com, 2009. 324 p.

10. Maugham W. S. Of Human Bondage. URL: https://www.e-reading.club/bookreader.php/80509/Maugham_Of_ Human_Bondage.htm.

11. Murdoch I. The Black Prince. URL: https://www.e-reading.club/ bookresder.php/104708/blackprince.pdf.

12. Plowman K. D., Wilson Ch. Strategy and Tactics in Strategic Communication: Examining their Intersection with Social Media Use. International Journal of Strategic Communication, 2018. Vol. 12: Iss. 2, P. 125-144. DOI: 10.1080/1553118X.2018.1428979.

13. Sinclair U. The Jungle. URL: https://etc.usf.edu/lit2go/77/the-jungle/1261/chapter-1. 